\title{
励起蛍光マトリクス計測を応用した デオキシニバレノールの新規判別法
}

\author{
藤田かおり，蔦 瑞樹 $，$ 杉山純一 \\ 独立行政法人農業・食品産業技術総合研究機構食品総合研究所
}

\author{
Detection of Deoxynivalenol in Water Solution \\ by Using Excitation-Emission Matrix
}

\author{
Kaori Fujita, Mizuki Tsuta ${ }^{\S}$ and Junichi Sugiyama \\ National Food Research Institute, National Agriculture and Food Research \\ Organization, 2-1-12, Kannondai, Tsukuba, Ibaraki 305-8642
}

\begin{abstract}
Excitation-emission matrix (EEM) fluorescence spectroscopy was used to detect deoxynivalenol (DON), which is a mycotoxin and is the most frequent contaminant occurring in toxicologically relevant concentrations in wheat and other cereal grains. Concentration gradients of DON aqueous solution samples with 7 levels were prepared as follows : 0, 4, 8, 125, 250, 500 and $1000 \mathrm{ppm}$. EEM was measured using a spectrofluorometer. DON could be characterized by some fluorescence peaks in EEM, especially those with the following specific excitation (Ex) and emission (Em) wavelength ranges : Ex 200 240 nm/Em $300 \mathrm{~nm}$ and Ex 250 300 $\mathrm{nm} / \mathrm{Em} 250 \sim 350 \mathrm{~nm}$. Through discriminant analysis of EEM, two groups of DON and pure water can be discriminated with the following three wavelength conditions : Ex $210 \mathrm{~nm} / \mathrm{Em} 270 \mathrm{~nm}$, Ex $240 \mathrm{~nm} / \mathrm{Em} 620$ $\mathrm{nm}$ and Ex $280 \mathrm{~nm} / \mathrm{Em} 330 \mathrm{~nm}$. For these conditions, a linear discriminant model was able to identify DON solutions with a classification accuracy of $100 \%$.
\end{abstract}

(Received Jun. 12, 2007 ; Accepted Jan. 29, 2008)

\footnotetext{
Keywords : deoxynivalenol (DON), excitation-emission matrix (EEM), fluorescence spectroscopy, mycotoxin, discriminant analysis

キーワード：デオキシニバレノール，励起蛍光マトリクス，蛍光分光光度計，マイコトキシン，判別分析
}

カビ毒污染はヒトや家畜などに対して急性もしくは慢性 の生理的・病理的障害を与えるために, 食品の安全性や安 定供給の観点から常に重要な問題である ${ }^{1) ~ 3)}$. また近年で は食糧や飼料の輸出入の増加に伴いカビ毒の拡散が懸念さ れている1) 3).

中でも，デオキシニバレノール (Deoxynivalenol, DON) は, ムギ・トゥモロコシ類などの禾穀類に污染が見られる カビ毒の 1 種である ${ }^{3) \sim 5)}$. DON 污染は, 一般土畩細菌であ るFusarium 属が原因であることから，その被害は世界各 地で報告されている5) 7). また穀類は食料としてだけでな く飼料としても利用価值が高いため, 穀類の DON 污染は, 農産物の収量・品質低下を招くばかりでなく家畜への深刻 な被害を与えている 合同食品添加物専門家会議 (Joint FAO/WHO Expert Committee on Food Additives, JECFA）拈よび Codex 食品 添加物 - 污染物質部会 (Codex Committee on Food Ad-

干305-8642 茨城県つくば市観音台 2-1-12

$\S$ 連絡先 (Corresponding author), mizukit@affrc.go.jp ditives and Contaminants, CCFAC) において DON のリ スク管理についての議論が開始され ${ }^{3)}$ わが国でも 2002 年 5 月に厚生労働省が，コムギの DON に関しての暫定基準 値を $1.1 \mathrm{ppm}$ として定めた.

一方, 食品安全性確保の観点から, 簡便性, 迅速性, 判 定の容易さ, 正確さ，低コスト等の特色を兼ね備えた新た な DON 検知法が必要とされており ${ }^{9)}$, これまであ精度や 感度を高めるために様々な検出法が試みられている ${ }^{10) \sim 12)}$. またわが国では，食発第 0521001 号平成 14 年 5 月 21 日付 け厚生労働省医薬局食品保健部長通知において, DON 定 性及び定量試験をUV 検出器付き高速液体クロマトグラ フィー (High-Performance Liquid Chromatography UV Detector, HPLC - UV) や電子捕獲検出器付きガスク ロマトグラフィー（Gas Chromatography-Electron Capture Detector, GC-ECD）で行うこと，また平成 15 年 4 月 には 15 食糧第 166 号食糧庁計画課流通部消費改善課通知 により機器分析以外に酵素免疫測定吸着法 (Enzyme Linked Immunosorbent Assay, ELISA）を活用できるこ 
とが示されている. しかし, 同通知にはこれら手法に十分 な習熟を必要とする旨が付記されており, 複雑な前処理や 測定結果を出すまでに時間を要することなどが問題となっ ている.

そこで本研究では, 比較的操作性のよい蛍光分光光度 計 ${ }^{13)}$ に着目し, DONの励起蛍光マトリクス（ExcitationEmission Matrix, EEM) 計測を行うこととした. EEM と は任意の励起波長ごとに計測された蛍光スペクトルの变化 を励起波長, 蛍光波長, 蛍光強度の 3 つの直行軸からなる 空間座標に示したものである. 数百次元に及ぶ膨大な情報 をむつ EEM のデー夕を解析することで, 数波長のデー夕 しか得られない通常の蛍光計測で見落とされる情報の収集 が可能となる ${ }^{14)}$. 17). また, EEM は成分固有の蛍光特性に よって特徴的なパターンを示すため, あらかじめ目標成分 の EEM を計測しておくことで物質の同定も可能となり, 様々な混在系における特定物質の同定や食品中の異物検出 などに応用されている ${ }^{14)}$ 17). これらの知見から, EEM 計 測を用いることでこれまで無色で蛍光も微弱とされる DON の検出が可能になると考えられた。本研究では, 蛍 光分光光度計を用いて DON の EEM を計測・解析するこ とで, DON の新規判別方法の検討を行い, カビ毒の簡便 な非破壊計測法開発に資する知見を得ることを目的とし た. 解析では判別関数 (Discriminant Function, $D F$ ) およ び判別関数の变数の算出を行い, DON の判別に有効な波 長の特定を試みた。

\section{材料および方法}

\section{1. 試薬および調整}

DON 標準試薬にはマイコトキシン試験用試薬（和光純 薬工業(株)）の製造日の異なる 2 ロット（No. LTL1755, No. WKQ3265）の試薬を用い, 純水には Milli-Q システム (MILLIPORE Biocel A10, 日本ミリポア(株)）を用いた. DON 標準試薬は純水で 0，4，8，125，250，500 および 1000 ppm の 7 段階に希釈し, 超音波洗浄機 US-4（(株)エ スエヌディ）で 15 分脱気を行い, DON 溶液とした。 なお 試薬調整には, $1.5 \mathrm{~mL}$ と $2.0 \mathrm{~mL}$ のイクロチューブ (Cat. No. A. 150, (株)アシスト, Cat. No. 508-GRD, Quality Scientific Plastics Inc.), $15 \mathrm{~mL}$ の遠心チューブ (Cat. No. 62. 554. 001, SARSTEDT AG \& Co.) および $1000 \mu \mathrm{L}$ と $5000 \mu \mathrm{L}$ のピペットチップ (Cat. No. 111-Q, Cat. No. 090-Q, Quality Scientific Plastics Inc.) を用いた。

\section{2. 蛍光分光光度計および解析ソフト}

(1) 蛍光分光光度計

EEM の計測には, 蛍光分光光度計は F-7000（(株)日立 ハイテクノロジーズ) を用い, データオペレーションソフト にはFL Solutions 2.1 ((株)日立ハイテクノロジーズ) を 用いて計測およびデー夕取得を行った。 セルには $0.35 \mathrm{ml}$ のミクロセル（FM20-SQ-1, GL Sciences Inc.) を用いた.

\section{表 1 計測条件}

$\begin{array}{lr}\text { スキャンスピード } & 30000 \mathrm{~nm} / \mathrm{min} \\ \text { 励起/蛍光スリット幅 } & 10 \mathrm{~nm} \\ \text { 励起/蛍光取得間隔 } & 10 \mathrm{~nm} \\ \text { 励起波長範囲 } & 200 \sim 340 \mathrm{~nm} \\ \text { 蛍光波長範囲 } & 200 \sim 900 \mathrm{~nm}\end{array}$

\section{(2) 解析ソフト}

取得データの等高線図作製には計測に用いた FL Solutions 2.1 を用いた. データの前処理には表計算ソフト Excel 2003 (Microsoft Co.) を用い, データの解析およびグラフ 作成には, 統計解析ソフト JMP 6 (SAS Institute Inc.), Excel 2003 およびエクセル統計 2004 （(株)会社情報サー ビス）を用いた。

\section{3. 実験方法 \\ (1) EEM 計測}

本実験では，励起・蛍光側のスリット幅および計測波長 間隔は共に $10 \mathrm{~nm}$ に設定した。 また, 計測波長範囲は励起 波長範囲を 200～340 nm, 蛍光波長範囲は 200～900 nm と し， ホトマル感度を $900 \mathrm{~V}$ に設定し波長走査速度は 30000 $\mathrm{nm} / \mathrm{min}$ とした（表 1). この際の各試料は $300 \mu \mathrm{L}$ であり, 各濃度 3 反復で EEM デー夕を取得した。得られた各 DON 溶液の EEM の等高線図から純水と DON 標準試薬 (以下, DON とする）の蛍光が見られる波長範囲の特定を行った.

(2) EEM データの前処理

取得データに以下 3 つの前処理を適用し，分析に供した (困 1).

i ) 本実験での解析対象は励起光よりあ長波長側の EEM データである. 取得 EEM データには励起光よりあ 短波長側のデー夕も含まれるため, 取得デー夕から励起光 （各照射励起光士 $20 \mathrm{~nm}$ ) よりも短波長範囲のデー夕を除外 した.

ii）また取得データには, 励起光の散乱光および散乱光 の 2 次光, 3 次光, 4 次光などのデー夕処理上の外乱亡なる 波長条件が含まれる。そのため, それら範囲のデー夕 (2 次 光 : 励起光 $\times 2 \pm 30 \mathrm{~nm} ; 3$ 次光 : 励起光 $\times 3 \pm 30 \mathrm{~nm} ; 4$ 次 光 : 励起光 $\times 4 \pm 40 \mathrm{~nm}$ ）の除去を行った.

iii）各ロットから濃度毎にランダムに半分に分けたデー 夕を抽出し, キャリブレーション用のデータとバリデー ション用のデータ群とした。

(3) 正準判別分析

前処理により得られた 707 条件の EEM データを各 DON 溶液における 707 次元の蛍光強度データとみなし, DON と純水の 2 グループにおける判別分析により, 判別関数 $(D F)$ を算出した。判別分析には多变量解析の一手法であ る正準判別分析を用いた。 また正準判別分析の变数選択は 变数増減法を採用した。

変数増減法での変数選択は $F$ 值の大きい順に行い, モデ 
DONサンプル

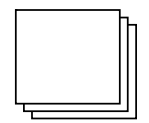

3 反復

×6サンプル

$\times 2$ ロット

純水サンプル

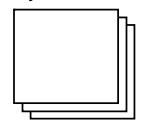

3反復

$\times 1$ サンプル

$\times 2$ ロット
$<$ 前処理のEEM >

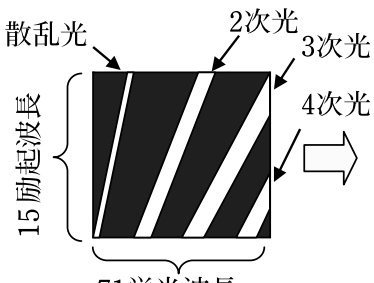

71 蛍光波長

$15 \times 71=1065$ 条件

*）全サンプルについて以下の工程を適応

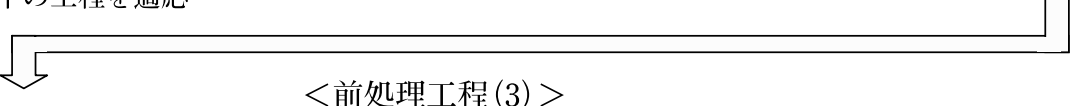

$<$ 前処理工程 (1) > 削除

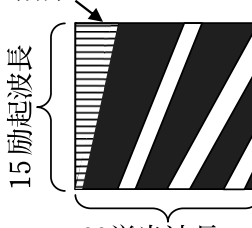

68 蛍光波長

1065－削除領域 $=915$ 条件
$<$ 前処理工程 $(2)>$

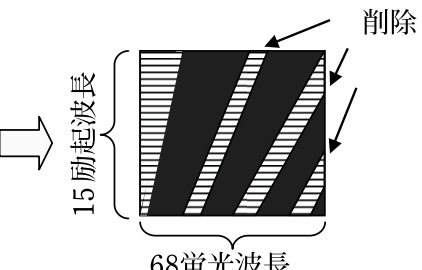

68 蛍光波長

915一削除領域 (2, 3, 4次光) $=707$ 条件

$<$ 前処理工程 $(3)>$
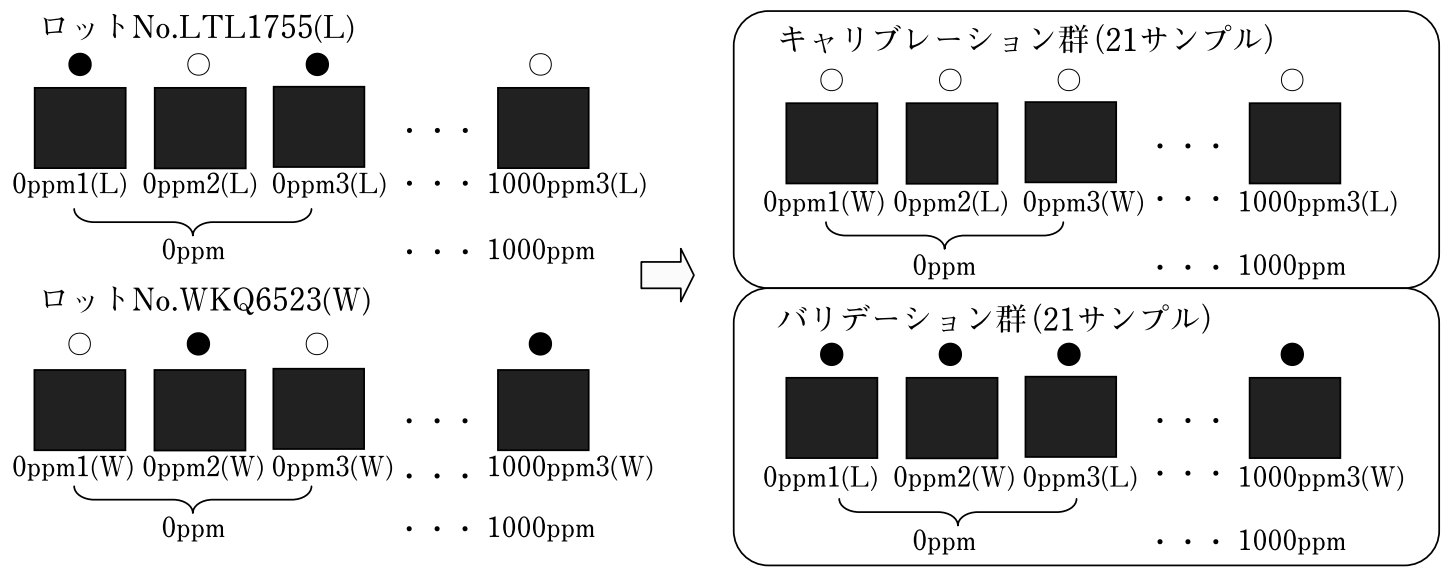

図 1 EEM の前処理工程

ルへの組み込みおよび除外は $p$ 值 $($ Prob $>F)$ を基準に 0.25〜0.05 を目安の值とした。 ただし，モデル取り込みの 際にすでに取り込まれた变数の最大 $F$ 值と新規变数の $F$ 值の比が $1 / 10$ 以下の時には, その变数はモデルに組み込 まなかった18).

\section{実験結果および考察}

\section{1. 励起蛍光マトリクス計測}

各 DON 溶液の EEM は，蛍光の特徵を観察するために 等高線図化した。 また EEM の等高線図はロットNo. LTL 1755 のデータを代表として図 2 に示した。等高線は最大值 を 3000 ，等高線間隔を 100 とした蛍光強度を示している. さらに図 2 中において, 励起波長 $200 \mathrm{~nm}$ 時の蛍光波長 200，400，600 および $800 \mathrm{~nm}$ を基点として長波長側に斜め に走る強度の強い発光は, 励起光の散乱光および 2 次光, 3 次光，4 次光であり，上記以外で短波長から長波長側に斜 めに走る発光はラマン散乱光であった ${ }^{13)}$. なお，図 2 の観 察では，主に 5 箇所に視覚的に識別可能な蛍光が確認され た。これら 5 箇所には補助的な印をつけた（図 $2 \mathrm{a} \sim \mathrm{e}$ ).

図 $2 \mathrm{~b}$ では，唯一明らかな蛍光ピークが観察できた。し かし，この蛍光ピークは DON 濃度と反比例的に蛍光強度 が高まる傾向であったことから，図 $2 \mathrm{~b}$ は純水が関与する
蛍光ピークであると推察された。 一方図 $2 \mathrm{a}$ では, 散乱光 とそのピーク位置が重なりピークの観察ができず, 図 $2 c$, d, e ではそのピークが測定範囲外にあり観察することがで きなかった。そのため，等高線の裾野の形状から DON 識 別および濃度との関係を検討した。

図 2a, c で観察された等高線は，0 ppm の溶液ではほと んど観察されなかった。また図 $2 \mathrm{a}$ の等高線は DON 濃度 が高まるとともに蛍光強度が高まることを示したが，図 $2 \mathrm{c}$ の等高線では濃度との明確な差異は見出すことができな かった。さらに図 $2 \mathrm{~d}, \mathrm{e}$ では， $0 \mathrm{ppm}$ を含めた全濃度での 差異を識別することは不可能であった。これらから，図 $2 \mathrm{a}$, c で確認できた等高線のみが DON 由来の蛍光であること が推察された，加えて，これまでの EEM を応用した事例 では，EEMの等高線図に見られるピークの裾野の形状む 物質の同定に用いている ${ }^{14) 15)}$ 。このため, 図 $2 \mathrm{a}, \mathrm{c} の$ 領域は DON 濃度の識別に有効であると考えられた。

そこで，これらの領域を中心に，等高線図の観察に留ま らず，さらに客観的に識別するために， EEM を数值化し判 別分析を用いて DON 判別および判別点の算出を試みた。

\section{2. 励起蛍光マトリクスデータの正準判別分析}

707 波長条件における蛍光強度を説明変数, DON およ び純水の 2 グループを基準変数とした判別分析をキャリブ 

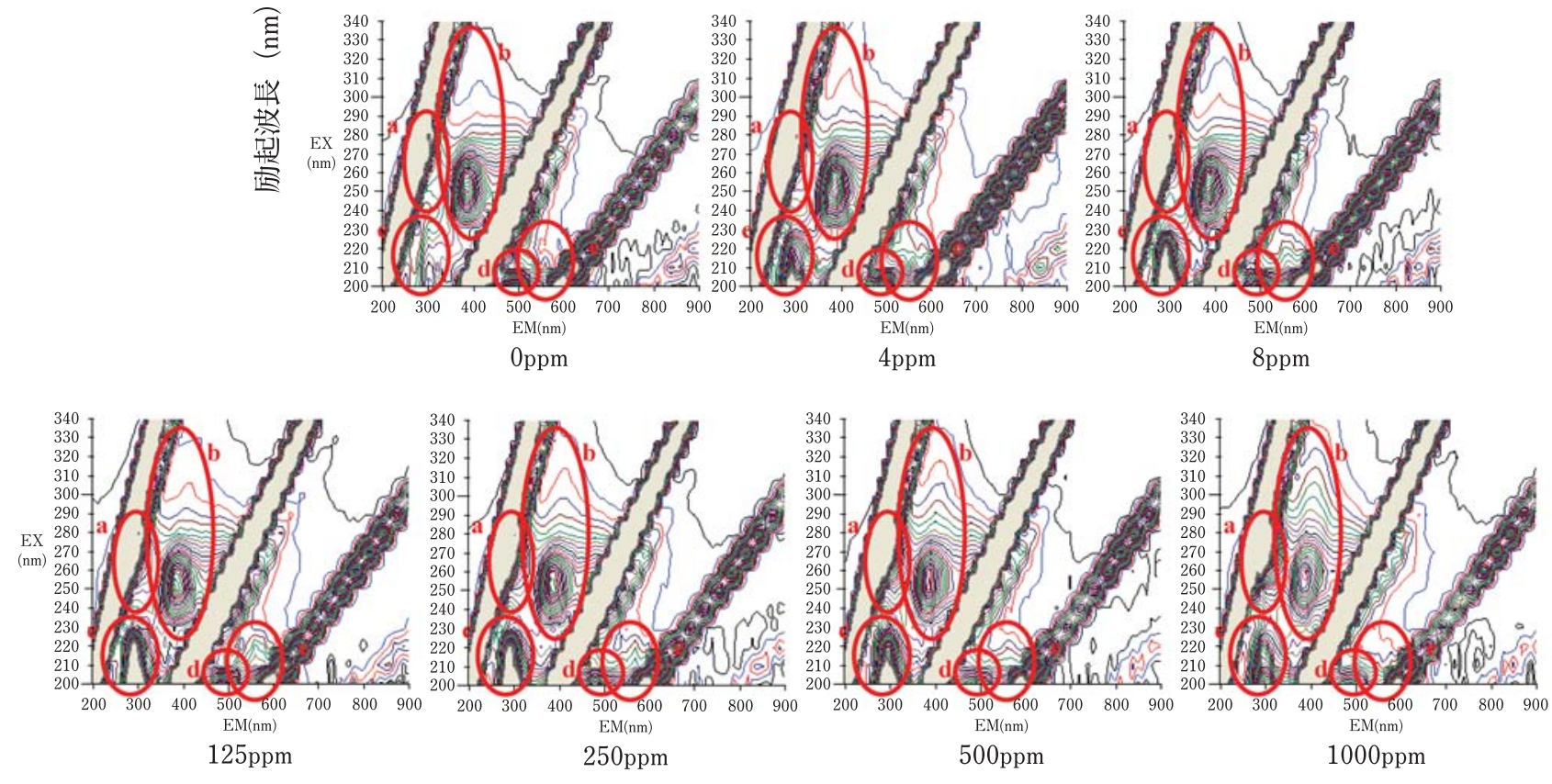

蛍光波長 $(\mathrm{nm})$

図 2 DON 溶液の EEM 画像

レーション群で行った。その結果, 励起波長 $200 \mathrm{~nm} /$ 蛍光 波長 $640 \mathrm{~nm}$, 励起波長 $200 \mathrm{~nm}$ /蛍光波長 $860 \mathrm{~nm}$, 励起波長 $230 \mathrm{~nm}$ /蛍光波長 $640 \mathrm{~nm}$, 励起波長 $260 \mathrm{~nm}$ /蛍光波長 460 $\mathrm{nm}$, 励起波長 $320 \mathrm{~nm}$ /蛍光波長 $830 \mathrm{~nm}$ の 5 つの変数が選 択された。 また各变数に対応して算出された係数から DON の判別関数モデル式(1)を得た.

$$
\begin{aligned}
D F= & -0.0112 x_{1}+0.0425 x_{2}-0.1099 x_{3} \\
& +0.0349 x_{4}+1.8922 x_{5}
\end{aligned}
$$

$x_{1}$ ：励起波長 $200 \mathrm{~nm}$ /蛍光波長 $640 \mathrm{~nm}$ 条件時の蛍光強度

$x_{2}$ ：励起波長 $200 \mathrm{~nm} /$ 蛍光波長 $860 \mathrm{~nm}$ 条件時の蛍光強度

$x_{3}$ ：励起波長 $230 \mathrm{~nm}$ /蛍光波長 $640 \mathrm{~nm}$ 条件時の蛍光強度

$x_{4}$ ：励起波長 $260 \mathrm{~nm}$ /蛍光波長 $460 \mathrm{~nm}$ 条件時の蛍光強度

$x_{5}$ ：励起波長 $320 \mathrm{~nm} /$ 蛍光波長 $830 \mathrm{~nm}$ 条件時の蛍光強度

上記判別式 (1) では, キャリブレーション群の判別はで きたむのの，バリデーション群で検証を行ったところ， デー夕数 21 点のうち 3 つの誤判別がされた.このため, 判 別式(1)では，DON と純水グループの明確な判別は不可能 であった。 また，この時に選択された変数は純水由来の蛍 光を示す波長条件を選択しており，DON 特有の条件を選 ぶことができなかった。

そこで， 2 波長領域（図 $2 \mathrm{a}, \mathrm{c}$ ) からあらかじめ各 1 つず
表 $2 \mathrm{DON}$ 判別関数に選択された波長条件および係数

\begin{tabular}{cr}
\hline \hline 励起波長/蛍光波長 & \multicolumn{1}{c}{ 係数 } \\
\hline Ex. 210/Em. 270 (nm) & 0.0104 \\
Ex. 240/Em. 620 (nm) & -0.0676 \\
Ex. 280/Em. 330 (nm) & 0.0052 \\
\hline
\end{tabular}

つ変数を選び, さらに変数増減法で変数を増すことで, DON 由来の蛍光による新たな判別式の算出を試みた。こ の際に固定した变数は, 各領域で DON の蛍光の值が純水 の值を上回った励起波長 $210 \mathrm{~nm}$ /蛍光波長 $270 \mathrm{~nm}$, 励起波 長 $280 \mathrm{~nm}$ /蛍光波長 $330 \mathrm{~nm}$ とした.

上記 2 変数を固定した変数増減法では, 判別関数に有効 な变数として，新たに励起波長 $240 \mathrm{~nm}$ /蛍光波長 $620 \mathrm{~nm}$ が選択された。 また，これらの変数に対応して，キャリブ レーション群から算出された係数は表 2 にまとめた。さら に表 2 の係数から以下の DON の判別モデル式 (2) を算出 した.

$$
\begin{aligned}
D F= & 0.0104 x_{1}-0.0676 x_{2}+0.0052 x_{3} \\
& +0.0349 x_{4}+1.8922 x_{5}
\end{aligned}
$$

$x_{1}$ ：励起波長 $210 \mathrm{~nm} /$ 蛍光波長 $270 \mathrm{~nm}$ 条件時の蛍光強度

$x_{2}$ ：励起波長 $240 \mathrm{~nm}$ /蛍光波長 $620 \mathrm{~nm}$ 条件時の蛍光強度

$x_{3}$ ：励起波長 $280 \mathrm{~nm}$ /蛍光波長 $330 \mathrm{~nm}$ 条件時の蛍光強度

判別式 (2)をバリデーション群に適用し, 判別関数におけ 


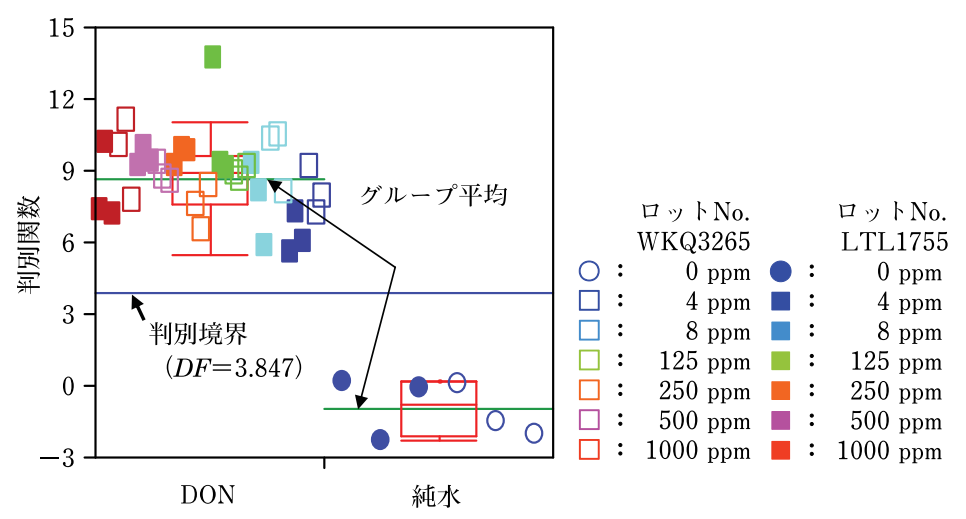

図 3 判別関数における DON および純水の判別状況

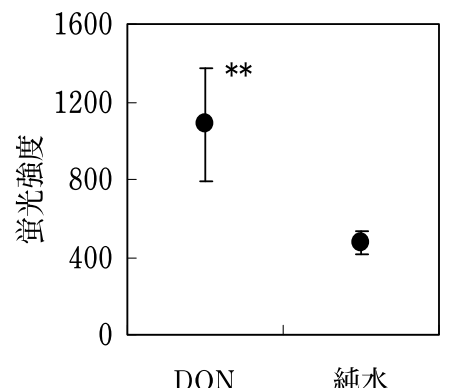

励起波長 $210 \mathrm{~nm} /$ 蛍光波長 $270 \mathrm{~nm}$

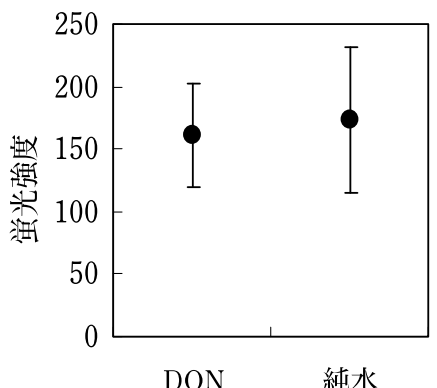

励起波長 $240 \mathrm{~nm} /$ 蛍光波長 $620 \mathrm{~nm}$

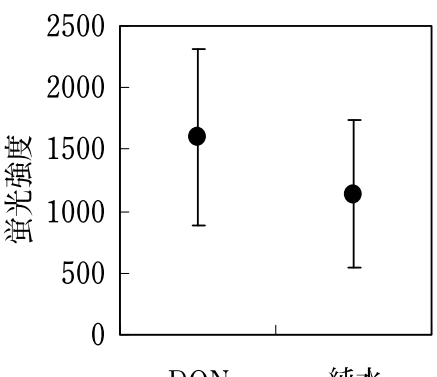

DON 純水

励起波長 $280 \mathrm{~nm} /$ 蛍光波長 $330 \mathrm{~nm}$

**：1\%で有意差あり

図 4 各波長条件での純水および DON の蛍光強度

る DON と純水の判別状況および両グループの分散は，箱 ひげ図を用いて図 3 に示した。図中における箱ひげ図の長 方形の中央の線は中央值，上下の辺がそれぞれ $25 \% ， 75 \%$ の 4 分位值を表しており，2つの分位值の差が 4 分位範囲 となる ${ }^{18)}$. また長方形の上下に伸びるひげの長さは上下 4 分位点土 $1.5 \times 4$ 分位範囲として算出され, ひげの外側に位 置するデー夕は外れ值と考えられる.

図 3 では, 判別式(2)を適応することにより, 誤判別もな く正判別率が 100\% であり, DON と純水の判別が可能と なることが示された。 また, 判別式(2)ではロットNo. LTL 1755 において $125 \mathrm{ppm}$ の DON 溶液に 1 つの外れ值が見 られたものの, 両グループ内およびロット間のばらつきは 少なく，高濃度の DON 溶液だけでなく低濃度の DON 溶 液に颃いても純水と完全に判別が可能であることが示され た。このことから, 判別式(2)によって, 低濃度の DON ま で識別できることが示唆された。しかしながら，判別式(2) により選択された $x_{2}$ は, 図 2 でピークが観察されない範囲 であった（図 2)。そこで，判別式 (2)で選択された各波長条 件における各グループおよびロットの分布についてさらに 検討を加えた。

判別式 (2) の変数となる各波長条件における DON およ び純水グループの蛍光強度の分布について，分散分析によ
る 2 グループの有意差検定を行った（図 4). 図 4 には検定 結果として, 両グループの平均值および標準偏差を示した.

図 4 加 ら, 励起波長 $240 \mathrm{~nm} /$ 蛍光波長 $620 \mathrm{~nm}$ (变数 $x_{2}$ ) では，純水とDON の值がほぼ同じ值であり，他の 2 波長 条件では純水の值を DON が上回ることが明らかになっ た。すなわち，図 2 のピークを外れた変数 $x_{2}$ は，判別式 $(2)$ においてDON に影響されない参照値として機能している と推察された。 また, 励起波長 $210 \mathrm{~nm} /$ 蛍光波長 $270 \mathrm{~nm}$ の波長条件 (变数 $x_{1}$ ) において, DON グループの蛍光強度 は純水グループよりも有意に高く $(p<0.01)$, さらに, 純水 の值にバラツキが少なかったことから，この波長条件が特 にDONの識別に重要となることが示唆された。

これらより, DON の有無の識別は, 本判別分析で選択さ れた 3 波長条件（DON に帰属する 2 条件とDON に影響 されない 1 条件）のみの計測により可能となることが示さ れた。

\section{結言}

本研究では数波長のみの情報しか得られない従来の蛍光 分析とは異なり, 数百次元に及ぶ膨大な情報をもつ EEM から得られるデー夕を解析することで, DON の判別が可 能となった。また DON 溶液と純水では EEM の等高線図 
に十分な差異がみられ, DON が特有の EEM を持つこと が明らかとなった。このことは光計測による DON 検知の 可能性を示唆する重要な情報であると考えられた。

これまでの EEM を用いた目的物質の定性に関する報告 では，EEMの等高線図における蛍光ピークを観察するこ とで識別を行っているが14115)，本実験では EEM 観察によ る完全な DON の判別は不可能であった，そこで，多変量 解析により EEM デー夕を解析することで, DON の判別に 関わる 3 つの波長条件を明らかにし，濃度に影響を受けな い判別関数を導き出した．今後は，さらに $1 \mathrm{ppm}$ 以下の濃 度の検証屯併せ，より堅牢な判別式の開発を試みるとと屯 に，これらの知見を基にコムギ粒やコムギ粉末などの混合 試料中の DON 検知について研究を進めていく予定である.

\section{要 約}

光計測によるカビ毒検知を試みた。本研究は光計測によ るデオキシニバレノール (Deoxynivalenol, DON) の判別 を可能にした初の試みであり，1）DON 溶液の励起蛍光マ トリクス（Excitation-Emission Matrix, EEM）計測, 2) EEM の数值化，3）多变量解析による DON の判別関数の 算出，の 3 段階で実験を遂行し，以下の知見を得た。

（1）これまで蛍光の検知が不可能とされていた DON に 招いて，励起波長 $200 ３ 40 \mathrm{~nm} /$ 蛍光波長 $200 ９ 00 \mathrm{~nm}$ の 範囲で DON 由来の蛍光が観察された。特に励起波長 200 ～240 nm/蛍光波長 $300 \mathrm{~nm}$, 励起波長 $250 \sim 300 \mathrm{~nm}$ /蛍光 波長 250〜350 nm 付近に観察されたピークは DON 特有の 蛍光ピークであると考えられた。

(2) 判別分析により，DON および純水の 2 グループの 判別には, 励起波長 $210 \mathrm{~nm}$ /蛍光波長 $270 \mathrm{~nm}$, 励起波長 $240 \mathrm{~nm}$ /蛍光波長 $620 \mathrm{~nm}$, 励起波長 $280 \mathrm{~nm} /$ 蛍光波長 330 $\mathrm{nm}$ の 3 つの変数が選択された。 またこの変数を用いた DON の判別関数の正判別率は $100 \%$ であり，誤判別がな かったことから，2つの溶液は 3 つの波長条件で十分に判 別が可能であった。

（3）さらにこれらのうち 2 波長条件において，DON 溶 液の蛍光強度が純水の值を上回っていたことから（ $p<$ 0.01), 今回算出されたモデル式が他の混合試料中での DON 判別に展開できる可能性が示唆された.

本研究は，独立行政法人日本学術振興会による若手研究 B の助成により実施された。本研究を遂行するに当たり, カビ毒および DON に関するご指導・ご助言をいただいた (独)農業環境技術研究所 生物生態機能領域 對馬誠也上 席研究員, 吉田重信主任研究員, 生長陽子氏に厚く感謝の 意を表します。

\section{文献}

1) D'Mello, J.P.F. and Macdonald, A.M.C., Mycotoxins, Animal Feed Science and Technology, 69, 155-166 (1997).

2）宇田川俊一，食品のカビ污染とリスクアセスメント，日本 医真菌学会雑誌，46，11-15（2005）。

3) FAO, Manual on the application of the HACCP system in mycotoxins prevention and control, FOOD AND NUTRITION PAPER, 73 (2001).

4) Mirocha, C.J., Pathre, S.V. and Christensen, C.M., Chemistry of Fusarium and Stachybotrys Mycotoxins. In "MYCOTOXIC FUNGI, MYCOTOXINS, MYCOTOXICOSES", Vol. 1, eds. Wyllie, T.D. and Morehouse, L.G., (Marcel Dekker, Inc., New), pp. 365-420, (1977).

5) Larsen, J.C., Hunt, J., Perrin, I. and Ruckenbauer, P., Workshop on trichothecences with a focus on DON : summary report, Toxicology Letters, 153, 1-22 (2004).

6) Tritscher, A.M. and Page, S.W., The risk assessment paradigm and its application for trichothecences, Toxicology Letters, 153, 155-163 (2004).

7) Placinta, C.M., D’Mello, J.P.F. and Macdonald, A.M.C., A review of worldwide contamination of cereal grains and animal feed with Fusarium mycotoxins, Animal Feed Science and Technology, 78, 21-37 (1999).

8) Cavret, S. and Lecoeur, S., Fusariotoxin transfer in animal, Food and Chemical Toxicology, 44, 444-453 (2006).

9）榊 浩行，1. 麦類の赤かび病防除及びマイコトキシン産生 制御技術開発の展開方向, 1-1 マイコトキシン暫定基準值 の設定と生産上の対応，冬作物研究，第 2 号，1-5（2002）.

10) Josephs, R.D., Derbyshire, M., Stroka, J., Emons, H. and Anklam, E., Trichothecenes: reference materials and method validation, Toxicology Letters, 153, 123-132 (2004).

11) Stroka, J., Spanjer, M., Buechler, S., Barel, S., Kos, G. and Anklam, E., Novel sampling methods for the analysis of mycotoxins and the combination with spectroscopic methods for the rapid evaluation of deoxynivalenol contamination, Toxicology Letter, 153, 99-107 (2004).

12) Klötzel, M., Schmidt, S., Lauber, U., Thielert, G. and Humpf, H.U., Comparison of different clean - up procedures for the analysis of deoxynivalenol in cereal . based food and validation of a reliable HPLC method, Chromatographia, 62 (1/2), 41-48 (2005).

13）田村善蔵，大幡利一，保田和雄編，「けい光分析」第 1 版, （講談社，東京）pp. 55-84（1974）.

14）下山 進，野田裕子，三次元蛍光スペクトルによる古代染 織遺物に使用された染料の非破壊的同定法，分析化学， 41 , 243-250 (1992).

15) Booksh, K.S., Muroski, A.R. and Myrick, M.L., Single measurement excitation/emission matrix spectrofluorometer for determination of hydrocarbons in ocean water. 2. Calibration and quantitation of naphtalene and styrene, Anal. Chem., 68, 3539-3544 (1996).

16）宮下一成，蔦 瑞樹，鈴木崇之，都 甲珠，杉山純一，中内 茂樹, 清水 浩, 3 次元スペクトルイメージングによるダイズ 種子の内部構造の可視化, 食科工, 51 (12), 656-664 (2004).

17) Park, B., Lawrence, K.C., Windham W.R. and Smith, D.P. Performance of hyperspectral imaging system for poultry surface fecal contaminant detection, Journal of Food Engineering, 75, 340-348 (2006).

18）廣野元久，林 俊克，「JMP による多变量デー夕活用術」, (海文堂，東京)，(2004).

(平成 19 年 6 月 12 日受付，平成 20 年 1 月 29 日受理) 